\title{
Analisis Kualitas Pelayanan Pajak Drive Thru Unit sPelayanan Cepat (UPC) Pada Samsat Rajabasa Lampung
}

\author{
Agustuti Handayani $^{1}$, Azza Fitria ${ }^{2}$ \\ Ilmu Administrasi publik, Fakultas Ilmu Sosial dan Politik, Universitas Bandar Lampung, \\ Jl. Zainal Abidin Pagar Alam No.26, Labuhan Ratu, Kedaton, 35142, Bandar Lampung, \\ Indonesia \\ E-mail: \\ Agustuti.handayani@ubl.ac.id \\ Azza.17111006@student.ubl.ac.id
}

\begin{abstract}
Service is an important factor for the government in serving the community if the services provided by the government are good, it will have a positive impact on government agencies and if the services provided are not good or bad, it will have a negative impact on these government agencies.The quality of Samsat Drive Thru UPC services can be seen from the services provided by the Samsat Drive Thru UPC officers who directly interact with the taxpayer community as for the quality provided by Samsat officers such as reliability, responsiveness to service speed, assurance, empathy and form. With the existence of the five quality standards These services can be assessed by the taxpayer community whether they are satisfied or not satisfied with the services provided by the Samsat Drive Thru UPC Officer.The purpose of the study is to find out how the form of services provided by the Samsat Drive Thru UPC officers to taxpayers, see how the quality of services provided by the Samsat Drive Thru UPC officers in increasing taxpayer satisfaction and knowing whether the taxpayer community is satisfied or dissatisfied with the services provided. given by the Samsat Drive Thru UPC officer. The method used in this research is qualitative with a descriptive approach.The results of the study show that the services provided by the Samsat Drive Thru UPC officers are good enough in serving the taxpayers, it's just that there is a lack of inadequate building facilities and it is not visible to the taxpayers that Samsat Rajabasa has Samsat Drive Thru UPC Assistant.
\end{abstract}

Keywords:Samsat Drive Thru,Service Quality,Customer Satisfaction,Taxpayer Society 


\begin{abstract}
Abstrak
Pelayanan merupakan faktor penting bagi pemerintah dalam melayani masyarakat jika pelayanan yang diberikan oleh pemerintah baik maka akan membawa dampak positip bagi instansi pemerintah begitu pula sebaliknya jika pelayanan yang diberikan kurang baik atau buruk maka akan berdampak negatif bagi instansi pemerintahan tersebut.Kualitas pelayanan Samsat Drive Thru UPCdilihat dari pelayanannya yang diberikan oleh petugas Samsat Drive Thru UPC yang langsung berinteraksi dengan masyarakat wajib pajak adapun kualitas yang diberikan oleh petugas samsat seperti Kehandalan, Ketanggapan kecepatan pelayanan, Jaminan, Empati dan Wujud.dengan adanya kelima standar kualitas pelayanan tersebut dapat dinilai oleh masyarakat wajib pajak apakah puas atau tidak puas dengan pelayanan yang diberikan oleh Petugas Samsat Drive Thru UPC.Tujuan Penelitian adalah mengetahui bagaimana bentuk pelayanan yang dilakukan oleh petugas Samsat Drive Thru UPC terhadap wajib pajak,melihat bagaiamana kualitas pelayanan yang diberikan oleh petugas Samsat Drive Thru UPC Dalam meningkatkan kepuasan wajib pajak dan mengetahui apakah masyarakat wajib pajak merasa puas atau tidak puas terhadap pelayanan yang diberikan oleh petugas Samsat Drive Thru UPC.Metode yang digunakan dalam penelitian ini adalah kualitatif dengan pendekatan deskritif.Hasil penelitian menunjukan bahwa pelayanan yang diberikan oleh petugas Samsat Drive Thru UPC sudah cukup baik dalam melayani masyarakat wajib pajak hanya saja terdapat kurangnya fasilitas gedung yang tidak memadai dan tidak terlihat oleh masyarakat wajib pajak bahwa Samsat Rajabasa memiliki Samsat Pembantu Drive Thru UPC.
\end{abstract}

Kata kunci: Samsat Drive Thru;Kualitas Pelayanan;Kepuasan Konsumen; Masyarakat Wajib pajak 


\section{Pendahuluan}

Pelayanan merupakan faktor penting bagi Pemerintah dalam melayani masyarakat jika pelayanan yang diberikan oleh instansi baik maka akan membawa dampak positif bagi instansi pemerintah begitu pula sebaiknya jika pelayanan yang diberikan oleh instansi tidak baik atau buruk maka akan berdampak negatif bagi instansi pemerintahan tersebut.Permasalahan yang dikeluhkan oleh masyarakat wajib pajak dalam melakukan transaksi pembayaran pajak yang terjadi di Samsat Drive Thru UPC Rajabasa yaitu: (1) Masyarakat wajib pajak sering mengalami kerumitan atau kesulitan dalam melakukan pembayaran pajak. (2) Pelayanan yang diberikan oleh pegawai Samsat kurang maksimal (3) Antrean yang cukup panjang pada saat masyarakat melakukan pembayaran pajak di kantor Samsat karena permasalahan waktu pelayanan tersebut masyarakat harus meninggalkan aktivitas atau pekerjaan mereka untuk membayar pajak dikarenakan oleh antrean yang panjang tersebut.Sistem pelayanan yang diberikan oleh Samsat Drive Thru UPC merupakan pelayanan yang menerapkan teknis transaksi pembayaran pajak dengan sistem Drive Thru atau melayani masyarakat wajib pajak yang menunggu di kendarannyamasyarakat wajib pajak yang ingin membayar pajak di Samsat Drive Thru UPC tidak perlu turun dari kendaraannya. Tetapi tidak hanya untuk masyakarat yang menggunakan sistem Drive Thru saja masyarakat juga bisa membayar pajak seperti biasa tidak menggunakan kendaraan atau drive thru. Adapun syarat-syarat masyarakat wajib pajak dalam membayar pajak kendarannya harus dengan menyiapkan dokumen lengkap seperti Fotocopy STNK dan E-KTP.

Kualitas Pelayanan Samsat Drive Thru UPC bisa dilihat dari pelayanan yang diberikan oleh petugas Samsat Drive Thru UPC yang langsung berinteraksi dengan masyarakat wajib pajak dengan adanya standar pelayanan dan pelayanan prima yang ditetapkan oleh Samsat Drive Thru UPC.adapun kualitas layanan yang diberikan oleh petugas Samsat Drive Thru seperti Kehandalan, Ketanggapan kecepatan pelayanan, Jaminan, Empati dan Wujud fasilitas yan diberikan.dari kelima standar tersebut apakah masyarakat wajib pajak puas atau tidak puas atas layanan yang diberikan Samsat Drive Thru. Kepuasan konsumen dapat membawa dampak positif bagi Samsat utnuk meningkatkan pendapatan asli daerah lampung begitupun sebaliknya ketidakpuasan konsumen akan membawa dampak negatif bagi samsat dan dapat menurunya Pendapatan Asli Daerah Lampung. Fasilitas pajak yang diberikan oleh petugas dimana pelayanan tersebut untuk memberikan kemudahan dan kenyamanan pelayanan bagi masyarakat wajib pajak Samsat Drive Thru UPC melayani Register atau transaksi pembayaraan Pajak Kendaran Bermotor pengesahan setiap tahun dan juga pembayaran Pajak Kendaraan Bermotor 1 (satu) tahun berjalan setiap satu tahun sekali.

Dari pernyataan tersebut terdapat tujuan dari penelitian saya yang berjudul Analisis Kualiatas Pelayanan Pajak Drive Thru Uni Pelayanan Cepat (UPC) Pada Samsat Rajabasa Kota Bandar Lampung yaitu untuk mengetahui bagaimana bentuk pelayanan diberikan oleh petugas Samsat Drive Thru UPC terhadap wajib pajak, melihat bagaimana kualitas pelayanan yang diberikan oleh petugas Samsat Drive Thru UPC dalam meningkatkan kepuasan wajib pajak dan mengetahui apakah masyarakat wajib pajak puas atau tidak puas terhadap layanan yang diberikan oleh petugas Samsat Drive Thru UPC. 


\section{Tinjauan Pustaka}

1.Konsep Kualitas Pelayanan

Konsep Kualitas

Menurut Kotler dan Keller(LENI JULISTA WATI, 2018) berpendapat bahwa kualitas adalah seluruh sifat dan ciri dari suatu pelayanan atau produk yang mempunyai kemampuan untuk memberikan kepuasan terhadap kebutuhan yang tersirat atau dinyatakannya.

Konsep Kualitas Pelayanan

Menurut Parasuraman Berry dalam Pasolognya 2011 (Hardiyansyah, 2018) dimensi pokok pelayanan meliputi 5 (lima) dimensi pokok kualitas pelayanan yaitu: (1) Reliability atau Kehandalan yaitu Kemampuan instansi atau organisasi untuk melaksanakan pelayanan jasa yang dijanjikan dengan tepat,handal,terpecaya,konsisten dan akurat sesuai terhadap pelayanan. (2) Responsiveness atau ketanggapan yaitu kesedian dan kemampuan untuk memberikan atau membantu pelayanan yang tepat dan cepat kepada pelanggan.(3) Assurance atau jaminan dan kepastian yaitu pengetahuan,kesopankaryawan dan kemampuan para pegawai perusahaan untuk menumbuhkan rasa percaya kepada para pelanggan kepada perusahaan atau instansi.(4) Empthy atau empati yaitu kondisi memberikan perhatian yang tulus dan bersifat individual atau pribadi yang diberikan kepada para pelanggan dengan berupaya memahami keinginan para pelanggan.(5)Tangibles atau bukti fisik yaitu kemampuan perusahaan dalam menunjukan ekstetensinya kepada pihak luar.Penampilan dan kemampuan prasarana dan sarana pada fisik perusahaan dimana keadaan lingkungan sekitar adalah bukti nyata dari pelayanan yang diberikan oleh petugas. Yang meliputi fasilitas fisik berupa gedung,peralatan dan perlengkapan teknologi yang digunakan serta penampilan berpakaian pegawai

\section{Konsep Pajak}

Menurut Rohmat Soemitro(Mardiasmo, 2013) Pajak merupakan iuran rakyat kepada kas negara berdasarkan Undang-Undang yang artinya dapat dipaksakan dengan tidak mendapat jasa timbal balik (kontraprestasi) yang berlangsung dapat ditunujukan dan digunakan untuk membayar pengeluaran-pengeluaranUmum.

Menurut Undang-Undang Nomor 28 Tahun 2007, mengenai peraturan umum dan tata caraperpajakan (KUP), perpajakan ialah pajak yang dibayarkan oleh masyarakat wajib pajak kepada negara dan pajak tersebut diberlakukan oleh orang atau badan sesuai dengan hukum kompensasi langsung untuk tujuan negara untuk sebesar-besar kemakmuran rakyat.

\section{Konsep Kepuasan Konsumen}

Menurut Philip Kotler(Putro et al., 2014) Kepuasan ialah perasaan bahagia senang atau kecewa bagi seseorangsebab ia merasakan perbandingan hasil dari suatu instansi atau kesan dari kinerja suatu perusahaan

Menurut Lovelock dan Wirtz (Putro et al., 2014), konsumen mengamati layanan dan konerja produk dan dengan membandingkan dengan harapan atau standar yang dimiliki oleh seseorang konsumen dan kemudian membuat keputusan yang memuaskan berdasarkan hasil perbandingan 


\section{Metodologi}

\section{Metode Penelitian}

Metode yang digunakan didalam penelitian ini adalah penelitian kualitiatif dengan desain metode penelitian deskriptif. Sumber data yang digunakan adalah data primer yang diperoleh langsung dari informan atau narasumber melalui wawancara dan data sekunder yang berupa dokumen-dokumen yang dimiliki oleh Samsat Drive Thru UPC. Dari hasil analisis datanya yang berupa lisan dapat ditulis oleh peneliti sebagai hasil wawancara terhadap informan atau narasumber.Penelitian ini dilakukan agar dapat menganalisis dan mendeskripsikan secara langsung analisis kualitas pelayanan pajak drive thru unit pelayanan cepat (UPC) pada samsat rajabasa kota Bandar lampung.

\section{Rancangan Penelitian}

1. Tempat Penelitian

Penelitian ini dilaksanakan di Samsat Drive Thru Unit Pelayanan Cepat (UPC) Rajabasa Kota Bandar Lampung yang beralamatkan di Samsat Rajabasa Jl.Pramuka NO.1 Rajabasa Bandar Lampung

2. Waktu Penelitian

Penelitianmulai dilakukan pada bulan November 2020 sampai dengan bulan Januari 2021

\section{Subjek Penelitian}

Subjek penelitian merupakan dimana pihak yang menjadi sumber informasi dalam suatu penelitian dan memiliki peran dan pengetahuan yang terpercaya serta informasi yang dibutuhkan sehingga peneliti dapat dengan mudah untuk memperoleh data atau observasi langsung dalam suatu fakta,pendapat dan kejadian-kejadian yang sesuai dengan permasalahan yang dibahas oleh peneliti.adapun informan yaitu Kepala UPTD Wilayah I Samsat Kota Bandar Lampung, Kepala Ruangan Samsat Drive Thru Unit Pelayanan Cepat (UPC) Wilayah I Samsat Kota Bandar Lampung, Staff Samsat Drive Thru Unit Pelayanan Cepat (UPC) Rajabasa dan Masyarakat Wajib Pajak.

\section{Teknik Pengumpulan Data}

1. Studi Kepustakaan (Library Research)

Studi kepustakaan untuk memperoleh data sekunder melalui serangkaian kegiatan mencatat,mengutip dan melihat badan pustaka yang berupa karya tulis dari para ahli atau sumber yang sudah tersusun dalam literature dan peraturan perundang-undangan yang berlaku serta ada kaitannya dengan permasalahan yang berkaitan dengan penulisan dan penelitian skripsi ini.

2. Studi Lapangan (Field Research)

Studi lapangan adalah bentukpenelitian yang dilakukan untuk memperoleh data primer.Dengan memperoleh data primer tersebut melakukan pengajuan meminta penjelasan dan pertanyaan kepada pihak terkait. Adapun metode yang dilakukan sebagai berikut:

1. Wawancara Mendalam

Wawanacara merupakan pengumpulan data yang dilakukan oleh peneliti melalui bertemu langsungatau tatap muka untuk mengajukan beberapa pertanyaan yang telah dibuat oleh 
peneliti dan melakukan sesi pertanyaan antara peneliti dan narasumber atau informan untuk memperoleh hasil kualitas pelayanan pada Samsat Drive Thru UPC.

2. Pengumpulan Dokumen-dokumen (tulisan-tulisan)

Peneliti dapat mengumpulkan beberapa bahan yang tertulis seperti dari media,surat menyurat dari sumber dan laporan untuk mencari informasi yang diperlukan untuk mengecek ketetapan atau kebenaran informasi yang diperoleh dengan wawancara terhadap narasumber atau informan.

\section{Observasi}

Agar peneliti dapat mengetahui sesuatu yang sedang terjadi atau sedang dilakukan pada tempat penelitian.dan jug peneliti melihat sendiri,merasakan sendiri dan mendengar sendiri dari tempat kejadian atau tempat penelitian .teknik pengumpulan observasi terlibat untuk memperoleh informasinya dari hasil observasi seperti tempat kegiatan,pelaku,waktu atau peristiwa dan kejadian langsung dalam melakukan observasi langsung.

4. Dokumentasi

Peneliti melakukan dokumentasi untuk memperlihatkan atau mendapatkannya sejumlah besar fakta dan data disimpan dalam bahan yang berbentuk dokumentasi seperti rekaman suara,foto dan dokumen lainnya sebagai hasil wawanacara antara peneliti dan narasumber terkait.

\section{Teknik Analisi Data}

1. Tahap Reduksi

Reduksi data artinya merangkum,memfokuskan,hasil wawancaraterhadap narasumber pada hal penting, memilih hal-hal yang pokok serta polanya.hasil penelitian dari lapangan sebagai bahan peneliti untuk menulis hasil wawancara langsung dirangkum kemudian disusun lebih relevan untuk difokuskan pada pokok hasil penelitian untuk mempermudah peneliti melihat kualitas pelayanan yang diberikan..

2. Tahap Display Data

Tahap ini merupakan data yang sudah dipilih dan diambil oleh peneliti selanjutnya peneliti melakukan kumpulan data dan hasil wawancara yang telah sebelumnya tahap reduksi data untuk menggambarkan kejadian yang ada dilapangan .hasil wawancara catatan yang ada dilapangan kemudian di sajikan dalam bentuk lebih ringkas untuk mempermudah melihat kualitas pelayanan yang ada.

3. Tahap Kesimpulan dan Verifikasi

Tahap terakhir dalam analisis data yang sebelumnya sudah diambil dan disusun selanjutnya penarikan kesimpulan dan verifikasi.Kesimpulan yang dibuat pada tahap awal didukung dengan bukti-bukti yang benar dan valid serta konsisten saat peneliti melakukan wawancara terhadap narasumber dan informan.hasil akhir dari analaisis data tersebut untuk dapat menemukan arti dari data yang telah diambil dan disajikan. Selanjutnya peneliti menarik hasil kesimpulan dan verifikasi untuk di analisis peneliti harus bisa menemukan argument dan gambaran serta makna yang mudah dipahami sehingga data tersebut dapat diperbandingkan dengan narasumber satu dan lainnya agar dapat menarik kesimpulan akhir sebagai jawaban-jawaban dari permasalahan yang dibuat oleh peneliti untuk melihat kualitas pelayanan yang diberikan. 


\section{Hasil dan Pembahasan}

Pelayanan faktor yang penting bagi pemerintahan pelayanan yang baik dan berkualitas dapat dilihat dari pelayanan yang diberikan petugas yang berinteraksi terhadap masyarakat public sebagai penerima pelayanan.Pada pembahasan peneliti akan mendeskripsikan tentang bagaimana Kualitas pelayanan yang diberikan oleh petugas Samsat Drive Thru Unit Pelayanan Cepat (UPC) Rajabasa. Dengan menggunakan teori konsep kualitas pelayanan menurut Zeithml Parasuraman Berry (2011:135) yaitu sebagai berikut:

\section{Kehandalan (Reliability)}

Kehandalan (Reliability) adalah kemampuan melaksanakan jasa yang dijanjikan dengan handal, terpecaya, tepat konsisten dan akurat sesuai terhadap pelayanannya. Petugas Samsat Drive Thru Unit Pelayanan Cepat (UPC) Rajabasa yang memiliki kehandalan melayani wajib pajak. Indikatornya dari Kehandalan meliputi: (1) Memberikan jasanya dengan waktu yang akurat.(2) Memberikan jasa dengan tepat dan benar pada saat pertama memberikan pelayanan. Hal tersebut sangat penting mengingat wajib pajak dengan membuktian pembuktian dari janji pelayanan yang diberikan oleh petugas Samsat.Peneliti melakukan observasi di Samsat Drive Thru Unit Pelayanan Cepat (UPC) Rajabasa dilihat dari penelitian yang berfokus pada bentuk kualitas pelayanan yang diberikan oleh Samsat Drive Thru Unit Pelayanan Cepat (UPC) Rajabasa.

Kepala ruangan Samsat Drive Thru UPC Rajabasa beliau mengungkapkan:

“ Bentuk pelayanan yang kami layani disini seperti waktu pelayanan yang diimulai daripukul 08.30 WIB selesai pada pukul 14.30 WIB jadi masyarakat wajib pajak bisa membayar pajak kendaraan mereka pada waktu yang sudah akurat tersebut.Selanjutnya kami petugas Samsat Drive Thru UPC melayani jasa dengan benar saat masyarakat wajib pajak datang seperti melihat kelengkapan STNK dan E-KTP dari wajib pajak tersebut jadi jika wajib pajak memiliki kekurangan kelengkapan dalam membayar pajak kami beritahu sebelumnya agar masyarakata melengkapi terlebih dahulu syarat-syarat atau kelengkapan dalam membayar pajak tersebut.Selanjutnya kami melayani wajib pajak di masa dengan adanya pandemic covid-19 masyarakat wajib menggunakan masker, menjaga jaraknya antara wajib pajak satu dan yang lainnya dan menyiapkan syarat untuk membayar pajak salah satu contoh STNK dan E-KTP di Fotocopy terlebih dahulu satu lembar setelah fotocopy baru di daftarkan setelah mendaftarkan mereka menunggu dipanggilkan untuk membayar pajaknya " (hasil wawancara pada tanggal 10 januari 2021)

Selanjutnya Peneliti mewawancarai Petugas Samsat Drive Thru UPC beliau mengungkapkan :

" Kami melayani masyarakat wajib pajak dimulai pukul 08.30 jadi sebelum kami melayani masyarakat wajib pajak kami petugas menyiapkan segala peralatan yang ada diruangan seperti Komputer dan Mic untuk memanggil masyarakat wajib pajak pada saat melakukan antrean dalam membayar pajak, tetapi jika semua peralatan sudah siap semua dan ternyata ada masyarakat yang datang ingin membayar pajak sebelum waktu dibuka pelayanan misal wajib pajak datang jam 08.15 kami juga melayaninya jika semua peralatan sudah siap mba" (hasil wawancara pada tanggal 10 januari 2021) 
Selanjutnya Masyarakat wajib pajak yang berada di Samsat Drive Thru UPC Beliau mengungkapkan:

"Menurut saya sih untuk waktu pelayanan operasional cukup jelas yah di tempel didepan kaca itu jadi masyarakat bisa datang diatas jam 08.30 WIB agar tidak menunggu terlalu lama pada saat samsat drive thru UPC buka dan prosedur bayar pajaknya pun dijelaskan oleh petugasnya harus fotocopy STNK dan E-KTP terlebih dahulu. Jadikan masyarakat yang baru pertama kali membayar pajak seperti saya ini bisa fotocopy terlebih dahulu persyaratannya sebelum mengikuti antrean mba" (hasil wawancara pada tanggal 19 januari 2021).

Dari hasil wawanacara bersama Kepala Ruangan Samsat Drive Thru Unit Pelayanan Cepat (UPC) Rajabasa, Petugas Samsat Drive Thru Unit Pelayanan Cepat (UPC) Rajabasa dan Masyarakat wajib pajak yang membayar pajak di samsat drive thru UPC pelayanan yang diberikan dalam waktu yang akurat dan jasa yang baik dan benar pada saat pertama pelayanan sudah baik dalam pelayanan publiknya semakin bagus pelayanan dan kualitas pelayanannya maka dapat meningkatkan kepuasan pelanggan masyarakat wajib pajak dalam membayar pajak tepat waktu. Jika masyarakatnya puas dengan pelayanan yang diberikan maka dapat meningkatkan bertambahnya julah pelanggan dan kepercayaan masyarakat dalam membayar pajak kendaraannya sebagai mana samsat merupakan salah satu pendapatan aseli daerah untuk meningkatkan pembangunan yang ada di Provinsi Lampung

\section{Ketanggapan (Responsiveness)}

Ketanggapan (Responsiveness), adalah kesediaannyapetugas dalam memberikan layanan dan membantu pelanggan pada tepat waktu. Petugas Samsat Drive Thru Unit Pelayanan Cepat(UPC) sigap dan siap untuk melayani masyarakat wajib pajak. Indikatornya dari ketanggapan seperti Pelayanan yang cepat dan tepat waktu bagi pelanggan,Selalu Menginformasikan Pelayanan dan Bersedia untuk membantu pelanggan yang berada dilingkungan Samsat Drive Thru UPC dan selanjutnya Siap dalam merespons permintaan wajib pajak.

Kepala Ruangan Samsat Drive Thru UPC beliau mengungkapkan:

"Kita Samsat Drive Thru UPC ini semaksimal mungkin secepatnya dalam melayani masyarakat dengan terlebih dahulu kita mengamati persyaratan dia untuk membayar pajak harus dengan EKTP dan STNK dan setelah persyaratan sudah cukup mereka baru membayar pajak waktunya sekitar 3 menit sampai dengan 5 menit,Selanjutnya juga kami selalu memberi informasi kepada wajib pajak apabila sudah masuk jam istirahat pada pukul 12.10 WIB sampai dengan pukul 13.00 WIB maka layanan akan dilanjutkan setelah jam istirahat dek" (hasil wawancara pada tanggal 10 januari 2021)

Selanjutnya Petugas Samsat Drive Thru UPC beliau mengungkapkan juga:

"Saya selaku petugas juga selalu bersedia untuk membantu wajib pajak yang baru pertama kali untuk membayar pajak salah satunya membayar pajak Bea Balik Nama Kendaraan jadi mereka harus mempersiapkan syarat-syarat yang harus lengkap seperti Surat Tanda Nomor Kendaraan (STNK) asli dan Kartu Tanda Penduduk (KTP) asli dan juga selalu sigap merespons pelanggan yang baru pertama kali membayar pajak di samsat UPC rajabasa memberitahu apabila wajib pajak menanyakan atau meminta lokasi tempat fotocopy atau tempat lainnya. Untuk lokasi 
tempat fotocopy di Samsat Drive Thru UPC ini sih dekat di depan kantor UPC jadi masyarakat wajib pajak tidak perlu kekantin atau kebelakang jauh-jauh untuk fotocopy persyaratnya membayar pajak" (hasil wawancara pada tanggal 10 januari 2021)

Selanjutnya Masyarakat wajib pajak yang berada di Samsat UPC beliau mengungkapkan:

"Saya baru pertama kali membayar pajak di Samsat Drive Thru ini Menurut saya sih untuk waktu pelayanan membayar pajaknya sangat cepat dan baik, saya tetap bisa berada didalam kendaraan saya saja lalu menyerahkan semua persyaratannya menunggu hanya sekitar kurang lebih 5 menit prosesnya sudah selesai mba. Persyaratannya sudah saya siapkan fotocopynya dari rumah jadi saya tidak perlu repot untuk fotocopy lagi sebab saya sebelumnya bertanya dengan tetangga saya yang sudah pernah datang membayar pajak di Samsat Drive Thru UPC ini "(hasil wawancara pada tanggal 15 januari 2021)

Selanjutnya masyarakat wajib pajak belau juga serupa mengungkapkan:

"Untuk waktu pelayanannya menurut saya sih lumayan cepat yaa sekitar 5 menitan saya senang sih petugasnya melayani dengan cepat karena banyak juga masyarakat diluar sana yang bilang masalah pelayanan bayar pajak yah mba yang katanya lama dan susah gitu, tapi menurut saya pribadi sih bagus pelayanannya dan cepat. Petugasnya juga baik sih menginformasikan harus fotocopy dulu persyaratnnya agar bisa mengikuti antrean. Jadi untuk masyarakat yang belum pernah atau belum paham bayar pajak sih bisa tau dan mengikuti prosedurnya " (hasil wawancara pada tanggal 10 januari 2021)

Dari hasil wawanacara bersama Kepala Ruangan Samsat Drive Thru Unit Pelayanan Cepat (UPC) Rajabasa, Petugas Samsat Drive Thru Unit Pelayanan Cepat (UPC) Rajabasa dan Masyarakat Wajib pajak yang membayar pajak di samsat drive thru UPC ketanggapan pelayanan petugas samsat drive thru UPC baik karena waktu peIayanan yang tepat dan cepat ini dapat meningkatkan kepuasan pelanggan masyarakat wajib pajak dalam membayar pajak kendarannya.jika masyarakat puas atas pelayanannya pada waktu yang tidak terlalu lama maka dapat meningkatkan kepuasan pelanggan dalam membayar pajak di Samsat Drive Thru UPC . Dan juga informasi tentang waktu pelayanan jelas masyarakat dapat mengetahui jam istirahatnya dan masyarakat dapat datang dibawah pukul 11.00 WIB dan diatas pukul 13.00 WIB agar tidak bertabrakan dengan jadwal istirahat dan tidak menunggu terlalu lama waktu pelayanan dibuka kembali pada siang hari. Selanjutnya yang terpenting saat petugas selalu siap dan cepat merespon permintaan pelanggan dengan baik dan maksimal maka kepuasan wajib pajak tersebut dapat meningkatkan hasil kepuasan pelanggan, jika pelanggan puas dengan pelayanannya maka dapat bertambahnya konsumen yang terus menerus membayar pajak di Samsat Drive Thru UPC tersebut.

\section{3) Jaminan (Assurance)}

Jaminan (Assurance) yaitu, kesopanan karyawan atau pengetahuan staf dengan kemampuan mereka untuk menunjukan keyakinan dan kepercayaan terhadap masyarakat wajib pajak. Para petugas Samsat Drive Thru Unit Pelayanan Cepat (UPC) Rajabasa diberikan pelatihan mengenai transaksi dalam pembayaran pajak menggunakan sistem komputer dan alat lainnya dan mengenai tata cara menyambut wajib pajak yang hendak membayar pajak kendaraannya. Indikatornya dari jaminannya yaitu: Membuat pelanggan yakin dan merasa aman 
dalam melakukan pembayaran pajak, karyawan yang menanamkan keyakinan kepada pelanggan, petugas yang selalu sopan dan ramah terhadap wajib pajak.

Kepala Ruangan Samsat Drive Thru UPC beliau mengungkapkan:

“ Kami membuat dulu masyarakat merasa aman dalam membayar pajak sebelum mereka membayar pajak kita pemberitahuan dahulu seperti contoh ada mobil truck. Truck itu ada truck kayu dan ada truck besi itu ada perubahan bayar pajaknya dari ketentuan baru kita beritahukan dahulu adanya perubahan pembayarannya bila mereka siap atau setuju kita teruskan untuk melanjutkan transaksi pembayaran pajak lalu mencetak Notice Pajaknya jadikan jaminan nya jelas sudah dijelaskan terlebih dahulu sbelum mereka membayar pajak, selanjutnya kami selalu memberi salam kepada masyarakat yang ingin membayar pajak misalnya jika waktu pagi dengan ucapan selamat pagi dan jika waktu siang selamat siang melihat dari waktunya tersebut jadi dengan adanya salam tersebut masyarakat itu juga dapat melihat kesopanan dan keramahan dari petugas samsat drive thru ini. Kalau kita petugas tidak ramah kita tidak bisa dekat dengan masyarakat maka masyarakat mungkin kurang mau membayar pajak di samsat drive thru UPC ini , kemudian untuk jaminan ada jaminan asuransi yang sudah ditetapkan oleh PT. Jasa Raharja jadi setiap masyarakat membayar pajak sudah ada juga langsung ketetapan dari PT. Jasa Raharja tersebut"(hasil wawancara pada tanggal 10 januari 2021)

Selanjutnya Petugas Samsat Drive Thru UPC beliau mengungkapkan:

"Kami selaku petugas samsat drive thru harus menamkan rasa percaya kepada masyarakat wajib pajak dalam melakukan transaksi pembayaran pajak karena kami sebelumnya sudah dilatih dengan baik dahulu dalam menerima transaksi msyarakat dalam membayar pajak kendarannya dan juga kami insa allah selalu dapat ramah kepada masyarakat wajib pajak sebab dengan keramahan dan kesopanan terhadap masyarakat wajib pajak maka masyarakat juga senang membayar pajaknya dengan mengucapkan salam sapaan selamat pagi atau selamat siang dengan waktunya. Jika masyarakat dapat menilai petugasnya ramah dan baik kan masyarakat puas dengan pelayan yang diberikan oleh kami "(hasil wawancara pada tanggal 10 januari 2021)

Selanjutnya masyarakat wajib pajak Samsat Drive Thru UPC beliau mengungkapkan:

"Saya selaku masyarakat wajib pajak merasa puas dengan kesopanan dan keramahan dari petugas samsat drive thru UPC ini. Dengan adanya sapaan ucapan itu kan masyarakat jadi senang membayar pajaknya mba, karena kan tidak banyak juga namanya pelayanan ya mba jadi ya ada yang cuek gitu aja cuman ya tergantung dari petugasnya sih mba. Tetapi pelayanan di samsat drive thru UPC ini baik terhadap saya yang baru membayar pajak sih. Dan juga untuk jaminan asuransinya cukup baik yang di buatkan oleh Jasa Raharja sendiri dalam bertransaksi karena sebelum membayar pajak di beritahukan dahulu jumlah dari total bayar pajaknya jadi masyarakat bisa membayar pajak sesuai notice pajak yang sudah dicetak dan juga untuk uang yang kami berikan kepada petugas dihitung lagi agar tidak ada selip uangnya dalam transaksi membayar pajak ini"“ (hasil wawancara pada tanggal 15 januari 2021)

Selanjutnya masyarakat yang berada di Samsat Drive Thru UPC beliau serupa mengungkapkan:

" Menurut saya untuk keramahan dan kesopanan petugas samsat drive thru UPC ini cukup baik sih. Proses saya dari datang tadi sih lumayan lama karena antre di fotocopyan saya harus 
memfotocopy dulu persyaratannya baru bisa mengikuti antrean kata petugasnya. Harapan saya sih untuk keramahan dan kesopannya selalu ditingkatkan yaa..karena banyak juga masyarakat yang mengeluh terhadap pelayanan publik di bandar lampung ini" (hasil wawancara pada tanggal 10 januari 2021)

Dari hasil wawanacara bersama Kepala Ruangan Samsat Drive Thru Unit Pelayanan Cepat (UPC) Rajabasa, Petugas Samsat Drive Thru Unit Pelayanan Cepat (UPC) Rajabasa dan Masyarakat Wajib pajak yang membayar pajak di samsat drive thru UPC peneliti yang melakukan observasi langsung bentuk jaminan yang diberikan oleh petugas Samsat Drive Thru cukup baik dari hal keamanan dalam bertransaksi yang dilakukan antara petugas dan wajib pajak keamanan yang langsung ditetapkan dari pusat dan asuransi yang diberikan oleh PT Jasa Raharja langsung cukup jelas sebab transaksi yang aman dapat meningkatkan kepercayaan masyarakat untuk membayar pajak di Samsat Drive Thru UPC. Selanjutnya untuk kesopanan petugas samsat drivve thru UPC dalam melayani masyarakat wajib pajak sangat baik setiap masyarakat wajib yang datang ke Samsat Drive Thru UPC. Para petugas mengucapkan salam dan sapaan kepada masyarakat wajib pajak dengan ucapan tersebut selamat pagi atau selamat siang tergantung waktunya dan selalu ramah menerapkan senyum,sapa dan salam tersebut jadi masyarakat puas dengan bentuk layanan yang diberikan oleh petugas Samsat Drive Thru UPC.

\section{4) Empati (Emphaty)}

Empati (Emphaty) yaitu, kondisi memberikan dan memperhatikan perhatian pribadi kepada konsumen atau masyarakat wajib pajak. Petugas Samsat Drive Thru Unit Pelayanan Cepat(UPC) selalu memberikan perhatian para wajib pajak yang membayar pajak kendaraannya. Indikator dari empati meliputi: Petugas yang memahami kebutuhan pelanggan dan Mengutamakan kepentingan terbaik wajib pajak.

Kepala Ruangan Samsat Drive Thru UPC beliau mengungkapkan:

" Di Samsat Drive Thru ini kami para petugas semaksimal mungkin berupaya memberikan pelayanan yang cepat dan juga mudah kepada masyarakat wajib pajak yang membayar pajak di Samsat Drive Thru UPC ini dan juga kami memberitahukan kepada masyarakat jika masyarakat mengetahui bahwa adanya masa calo dari petugas yang berada disamsat rajabasa untuk segera melaporkan kepada pihak samsat. Sebab kami para petugas samsat drive thru upc memberikan pelayanan sesuai dengan standar pelayanan prima samsat untuk melayani masyarakat wajib pajak kemudian kami petugas mengutamakan kepentingan masyarakat wajib pajak. Petugas dilarang untuk meninggalkan urusan kantor jika tidak ada kepentingan mendesak dari pegawai dan petugas samsat drive thru harus fokus dalam mengerjakan pekerjaan mereka dek"(hasil wawancara pada tanggal 10 januari 2021)

Selanjutnya Petugas Samsat Drive Thru UPC beliau serupa mengungkapkan:

"Kami petugas samsat drive thru upc ini insya allah memberikan pelayanan mudah sesuai dengan pelayanan publik dek untuk meningkatkan kualitas pelayanan samsat drive thru upc. Dan juga kami para petugas selalu berusaha fokus pada pekerjaan kami dalam melayani masyarakat wajib pajak kami istirahat hanya dijam istirahat saja selanjutnya melayani masyarakat wajib pajak untuk membayar pajak" (Hasil wawancara pada tanggal 15 januari 2021)

Selanjutnya masyarakat wajib pajak Samsat Drive Thru UPC beliau mengungkapkan: 
“Saya sebagai masyarakat wajib pajak melihat empati yang diberikan oleh petugas Samsat Drive Thru UPC cukup puas dengan keramahan dan kecepatan petugas dalam melayani saya yang baru membayar pajak. Dengan kemudahan dan kecepatan petugas samsat drive thru upc ini dapat mengurangi adanya calo. Sebab masih banyak juga mba yang bilang kalau bayar pajak itu susah dan lama gituloh.mungkin ini sih yang menyebabkan adanya calo untuk memproses dan mempermudah bayar pajak kendaraan.tetapi saya melihat petugas di samsat drive thru ini baik sih dan ramah juga melayani saya yang baru membayar pajak dan prosesnya juga tidak lama kok yah asalkan persysratan kita lengkap" (Hasil wawancara pada tanggal 15 Januari 2021)

Dari hasil wawanacara bersama Kepala Ruangan Samsat Drive Thru Unit Pelayanan Cepat (UPC) Rajabasa, Petugas Samsat Drive Thru Unit Pelayanan Cepat (UPC) Rajabasa dan Masyarakat Wajib pajak yang membayar pajak di samsat drive thru UPC peneliti yang melakukan observasi langsung bentuk Empati yang diberikan oleh petugas Samsat Drive Thru UPC sudah baik dengan mengedepankan dan mengutamakan kepentingan terbaik pelanggan sesuai dengan standar pelayanan dan maklumat pelayanan Samsat Drive Thru UPC ini dapat memberikan kepuasan terhadap masyarakat wajib pajak. Pelayanan yang cepat dan mudah ini masyarakat puas terhadap bentuk pelayanan pubik yang ada di Samsat Rajabasa dan untuk mengurangi calo yang ada di lingkungan pelayanan publik ini.Petugas yang bekerja semaksimal cepat dan mudah ini untuk meningkatkan kepuasan masyarakat wajib pajak agar pendapatan daerah semakin meningkat dengan bertumbuhnya kepercayaan masyarakat oleh petugas yang mementingkan kepentinggan pelanggan.

\section{5) Wujud (Tangible)}

Wujud (Tangible) merupakan penampilan fasilitas fisik Gedung, peralatandan bahan komunikasi dalam pelayanan. Fasilitas yang ada di Samsat Drive Thru Unit Pelayanan Cepat (UPC) Rajabasa membantu mempercepat dalam pembayaran pajak kendar aan bermotor. Indikator dari wujud meliputi: Fasilitas peralatan modern di Samsat Drive Thru UPC dan Petugas yang memiliki penampilan rapid an professional.

Kepala Ruangan Samsat Drive Thru UPC beliau mengungkapkan:

"Fasilitas yang dimiliki oleh Samsat Drive Thru ini sudah sangat cukup dan lengkap dek diluar kita menyiapkan segala perlengkapan untuk melayani masyarakat wajib pajak dan dengan adanya covid-19 ini kita juga menyiapkan standar covid dari protocol kesehatan pada waktu pandemic ini seperti memakai masker, menjaga jarak dalam antrean didepan dan mencuci tangan. Dan pekerja-pekerjanya artinya untuk melayani masyarakat wajib pajak sudah sangat profesional dan mereka sudah sangat teruji.Kedua kita sangat santun dan sopan kepada masyarakat wajib pajak. Untuk jumlah fasilitas komputer di Samsat Drive Thru ini ada 4 buah jadi setiap pegawai penetapan ada komputer masing-masing, alat cetak scanner untuk notice pajak berjumlah 3 buah dan juga Mic 1 buah untuk memanggil dan mengumumkan terhadap masyarakat wajib pajak. Selanjutnya petugas samsat drive thru UPC selalu menggunakan pakaian rapi dan seragam kantor untuk melayani masyarakat wajib pajak" (hasil wawancara pada tanggal 10 januari 2020)

Selanjutnya Petugas Samsat Drive Thru UPC beliau serupa mengungkapkan:

“ Untuk fasilitas kami para petugas penetapan dan pendapataan memiliki masing-masing fasilitas komputer yang disediakan untuk melayani masyarakat wajib pajak. Tidak hanya untuk 
para petugas saja fasilitas yang ada di Samsat Drive Thru UPC ini untuk masyarakat wajib pajak juga di sediakan fasilitas Internet/Wifi untuk masyarakat wajib pajak yang berada di lingkungan Samsat Drive Thru UPC dan juga untuk fasilitas yang baru Samsat Pusat menyediakan dengan sistem pengecekan online pembayaran pajak kendaraan melalui google playstore cek pajak kendaraan provinsi lampung.Jadi masyarakat bisa mengecek total pajak kendaraannya yang sudah lama melalui internet saja"(hasil wawancara pada tanggal 10 januari 2020)

Selanjutnya masyarakat wajib pajak Samsat Drive Thru UPC beliau mengungkapkan:

"Menurut saya untuk fasilitas yang ada di Samsat Drive Thru ini cukup puas mba, dengan disediakannya WIFI untuk masyarakat wajib pajak yang sedang menunggu antrean sambil menikmati WIFI yang tersedia mba. Dan juga saya sebagai masyarakat awam baru mengetahui bahwa kita sebagai masyarakat wajib pajak yang ada disni atau diluar kota bandar lampung bisa mengecek pajak kendaraan melalui internet jadi untuk memudahkan masyarakat wajib pajak seperti saya sebelum m enyiapkan uang untuk membayar pajak sesuai dengan ketentuan pajaknya mba "(hasil wawancara pada tanggal 15 januari 2021)

Dari hasil wawanacara bersama Kepala Ruangan Samsat Drive Thru Unit Pelayanan Cepat (UPC) Rajabasa, Petugas Samsat Drive Thru Unit Pelayanan Cepat (UPC) Rajabasa dan Masyarakat Wajib pajak yang membayar pajak di samsat drive thru UPC peneliti yang melakukan observasi langsung bentuk wujud yang diberikan oleh Samsat Drive Thru UPC cukup baik dengan fasilitas komputer,scanner mic dan internet yang tersedia dan lengkap dapat memudahkan petugas samsat dalam melayani masyarakat wajib pajak dan juga fasilitas yang disediakan oleh samsat drive thru upc terhadap masyarakat wajib pajak sangat baik dengan disediakannya fasilitas internet atau wifi untuk masyarakat yang sedang menunggu antrean membayar pajak di Samsat Drive Thru UPC dengan disediakannya fasilitas internet dan wifi masyarakat wajib pajak puas dengan fasilitas yang diberikan oleh Samsat Drive Thru UPC ini dapat meningkatkan bentuk pelayanan publik yang baik yang diberikan oleh petugas Samsat Drive Thru UPC.Selanjutnya fasilitas yang diberikan Samsat Drive Thru UPC untuk masyarakat dapat langsung mengecek jumlah pajak kendarannya melalui internet ini dapat mengurangi masa calo yang berada dilingkungan Samsat Drive Thru UPC. Dan selanjutnya peneliti melakukan observasi melihat petugas yang berada di Samsat Drive Thru UPC memiliki penampilan yang professional dan rapi menggunakan pakaian pakaian kantor dalam melayaninya masyarakat wajib pajak.

\section{Kesimpulan}

Berdasarkan hasil penelitian tentang Analisis Kualitas Pelayanan Pajak Drive Thru Unit Pelayanan Cepat (UPC) Pada Samsat Rajabasa. Peneliti dapat menyimpulkan bahwa pelayanan pegawai Samsat Drive Thru Unit Pelayanan Cepat (UPC) Rajabasa sudah efektif sehingga peneliti dapat menyimpulkan:

1.Pelayanan yang diberikan oleh Petugas Samsat Drive Thru UPC sudah sangat baik. Dengan adanya isu-isu diluar sana masyarakat sering sekali berasumsi bahwa pelayanan yang diberikan oleh instansi pemerintah dalam pelayanan publik termasuk pelayanan Samsat lama,berbelit dan lain-lain. Peneliti melihat langsung kinerja dari petugas Samsat Drive Thru UPC sudah sangat baik mulai dari dibukanya waktu pelayanan dan tutupnya waktu pelayanan sudah cukup jelas 
diinformasikan kepada masyarakat wajib pajak dan petugas samsat drive thru UPC hanya melayani masyarakat wajib pajak yang membawa syarat-syarat dan kelengkapan dalam membayar pajak seperti STNK dan E-KTP fotocopy. Jadi jika ada masyarakat yang ingin membayar pajak di Samsat Drive Thru UPC harus menyiapkan persyaratannya dengan lengkap agar cepat di proses oleh petugas Samsat Driv Thru UPC.Selanjutnya peneliti melihat langsung untuk waktu melayani masyarakat wajib pajak cukup baik hanya menunggu 3 menit sampai 5 menit saja waktu masyarakat wajib pajak menunggu untuk diproses pembayaran pajaknya dan juga pegawai samsat drive thru selalu sigap cepat merespon wajib pajak yang menanyakan tempat-tempat di Samsat seperti tempat Fotocpy, mushola dan juga kantin sebagaimana disiapkan untuk fasilitas masyarakat wajib pajak. Selanjutnya peneliti juga melihat petugas di Samsat Drive Thru UPC keramahan dan kesopanan sangat baik dalam melayani masyarakat wajib pajak. Petugas memberi sapaan kepada masyarakat wajib pajak dengan ucapan selamat pagi atau selamat siang sesuai waktunya dengan keramahan dan kesopanan tersebut masyarakat merasa puas atas pelayanan yang diberikan oleh samsat drive thru UPC. Selanjutnya peneliti melihat fasilitas yang ada di Samsat Drive Thru UPC cukup baik dari fasilitas peralatan dalam melayani wajib pajak sangat baik seperti tersedianya komputer, scanner dan juga fasilitas internet atau web yang disediakan oleh Samsat khusunya Samsat Drive Thru untuk masyarakat wajib pajak yang sedang menunggu transaksi pembayaran pajak dan juga web untuk mengecek besaran pokok pajak yang sudah ditetapkan oleh pusat dengan disediakannya web tersebut dapat mengurangi adanya pencaloan dari petugas Samsat ,Jadi masyarakat bisa mengecek total pembayaran pajaknya melalui aplikasi " Cek Pajak Kendaraan Provinsi Lampung" Peneliti melihat sangat baik dengan disediakannya fasilitas internet atau web untuk masyarakat wajib untuk meningkatkan kepuasan wajib pajak.

\section{Saran}

Berdasarkan penelitian tentang pelayanan Samsat Drive Thru Unit Pelayanan Cepat (UPC) Rajabasa yang telah peneliti lakukan terdapat beberapa saran:

1. Pelayanan Pemerintah dalam bidang pelayanan publik khususnya Samsat Rajabasa untuk mensosialisasikan kepada masyarakat pentingnya taat membayar pajak tepat waktu. Sebagaimana samsat merupakan salah satu Pendapatan Asli Daerah Lampung untuk pembangunan Provinsi Lampung.

2. Diharapkan Samsat untuk memperbesar atau memperluas gedung Samsat Drive Thru UPC. Karena masih sangat banyak sekali masyarakat yang kurang mengetahui bahwa Samsat Rajabasa memiliki Sistem pembayaran Drive Thru.

3. Melakukan evaluasi kepada masyarakat untuk tidak terpengaruh dengan adanya pencaloan. Jika masyarakat melihat atau ditawarkan oleh calo untuk membayar pajak di Samsat Rajabasa harap menolak dengan tegas dan segera melaporkan kepada pihak Samsat Rajabasa.

4. Diharapkan kepada petugas Samsat Drive Thru UPC untuk selalu meningkatkan kinerjanya dan juga berupaya untuk mempertahankan kualitas yang baik kepada masyarakat wajib pajak. 


\section{DAFTAR PUSTAKA}

Hardiyansyah. 2018. Kualitas pelayanan publik konsep,dimensi,indikator dan implementasinya. Gava media.

LENI JULISTA WATI. 2018. Analisis kualitas pelayanan ladies dan pengaruhnya terhadap kepuasan wajib pajak di sistem administrasi manunggal satu atap (samsat) mall bumi Kedaton Bandar lampung. Journal of materials processing technology, 1(1).

Mardiasmo. 2013. Perpajakan. Andi offset. Jogjakarta.

Putro, S., Semuel, H., \& Brahmana, R. (2014). Pengaruh Kualitas Layanan Dan Kualitas Produk Terhadap Kepuasan Pelanggan Dan Loyalitas Konsumen Restoran Happy Garden Surabaya. Jurnal Manajemen Pemasaran, 2(1).

Http://publication.petra.ac.id/index.php/manajemen-pemasaran/article/view/1404

Undang-Undang Nomor 28 Tahun 2007 tentang Tata Cara dan Ketentuan Umum Perpajakan (KUP) 